\title{
Pyöröpaalisäilörehun mikrobiologiset riskit maataloustyöntekijöille
}

Sirpa Rautiala, Päivi Rissanen ja Marjut Reiman

Kuopion aluetyöterveyslaitos, Pl 93,70701 Kuopio, etunimi.sukunimi@ttl.fi

\section{Tiivistelmä}

Tutkimuksessa selvitettiin maataloustyöntekijöiden altistumista ilman mikrobeille eri menetelmillä säilötyn timotei-nurminatapyöröpaalisäilörehun käsittelyn yhteydessä. Paalit oli säilötty käyttäen AIV2000-happosäilöntäainetta (happopaalit), Bioprofit-bakteeriymppisäilöntäainetta (ymppipaalit) tai niiden säilönnässä ei ollut käytetty säilöntäainetta lainkaan (painorehu). Paaleissa käytetyn rehun kuiva-ainepitoisuus oli korjuuhetkellä 26,7\% tai 39,1\%. Kiedontamuovikerroksia paaleissa oli kuusi.

Pyöröpaalisäilörehun käsittelyn aikana ilman mikrobipitoisuudet nousivat varsin korkeiksi. Happopaaleja käsiteltäessä elinkykyisten sienten pitoisuudet olivat $10^{3}-10^{5} \mathrm{cfu} / \mathrm{m}^{3}$ ja ymppi- ja painorehupaaleja käsiteltäessä $10^{3}-10^{4} \mathrm{cfu} / \mathrm{m}^{3}$. Kokonaisitiöpitoisuudet olivat $10^{6} \mathrm{kpl} / \mathrm{m}^{3}$. Eri säilöntämenetelmien välillä ei ollut tilastollisesti merkitseviä eroja. Paalien kuiva-ainepitoisuudella ei myöskään ollut vaikutusta altistustasoihin. Mikrobeja vapautui ilmaan myös sellaisten paalien käsittelyn yhteyssä, jotka olivat silmämääräisesti tarkastellen hyvännäköisiä.

Tutkimuksen tulosten perusteella maataloustyöntekijät voivat altistua korkeille mikrobipitoisuuksille pyöröpaaleihin säilötyn rehun jakamisen ja käsittelyn yhteydessä. Pitoisuudet voivat olla samaa suuruusluokkaa, mitä on aikaisemmin havaittu maataloudessa kuivaheinän ja kuivikkeiden käsittelyn aikana. Ilman mikrobipitoisuudet voivat olla korkeita myös sellaisten paalien käsittelyssä, joissa on silminhavaittavasti vain pieniä homelaikkuja tai homelaikkuja ei havaita lainkaan. Altistumista voi tapahtua myös säilöntäaineilla säilöttyjen pyöröpaalien käsittelyn yhteydessä.

Asiasanat: maataloustyö, säilörehu, ruokinta, altistuminen, mikrobit, homesienet, hiivasienet 


\section{Johdanto}

Homeet aiheuttavat maataloudessa työperäistä astmaa ja homepölykeuhkoa. Huippuvuosina 1980luvulla maataloustyöntekijöillä todettiin vuosittain satoja homepölykeuhkoja, mutta sen jälkeen niiden määrä on vähentynyt. Kuitenkin yhä edelleen diagnosoidaan vuosittain kymmeniä uusia ammattitautitapauksia, vaikka maataloudessa työskentelevien henkilöiden määrä vähenee. Erityisesti sateiset kesät näkyvät ammattitautitilastoissa. Esimerkiksi vuonna 1999 diagnosoitiin huonojen sadonkorjuusäiden seurauksena 116 homepölykeuhkotapausta, kun niitä on viime vuosina ollut keskimäärin 30-60 kpl/vuosi (Karjalainen ym. 1999, Karjalainen ym. 2000, Karjalainen ym. 2001, Karjalainen ym. 2002, Riihimäki ym. 2003 ).

Yhtenä syynä homepölykeukotapauksiin on pidetty homeisen kuivaheinän ja kuivikkeiden käsittelyn aikaista mikrobialtistumista. Kuivaheinän käyttö karjan rehuna on kuitenkin vähentynyt viime vuosikymmeninä. Säilörehun käyttö sen sijaan on lisääntynyt ja siitä on tullut monilla tiloilla ympärivuotinen nautakarjan perusrehu. Erityisesti säilörehun varastointi muovitetuissa pyöröpaaleissa on yleistynyt. Kuopion aluetyöterveyslaitoksen vuonna 2004 tekemän kyselyn mukaan pyöröpaalit olivat pääasiallinen rehunsäilöntämenetelmä 43\%:lla rehua tehneistä suomalaisista tiloista (Työterveys ja maatalous Suomessa 2004-tutkimus).

Ilman mikrobipitoisuuksille ei ole olemassa terveysperusteisia raja-arvoja. Ulkomaisissa tutkimuksissa $>10^{4} \mathrm{cfu} / \mathrm{m}^{3}$ olevilla home- ja hiivasienipitoisuuksilla on esitetty olevan haitallisia vaikutuksia ihmisten terveydelle (Heida ym. 1995). Suomalaisissa tutkimuksissa ilman home- ja hiivapitoisuudet ovat olleet homepölykeuhkoa sairastavien maataloustyöntekijöiden tiloilla suuruusluokkaa $10^{4}-10^{7} \mathrm{cfu} / \mathrm{m}^{3}$ (Kotimaa ym. 1984).

Pyöröpaalisäilörehun käsittelyn aikaista mikrobialtistumista ei ole juurikaan tutkittu, vaikka paalisäilörehun käyttö on lisääntynyt. Tämän tutkimuksen tavoitteena oli selvittää maataloustyöntekijöiden altistumista ilman mikrobeille kolmella eri menetelmällä säilöttyjen pyöröpaalien käsittelyn yhteydessä.

\section{Aineisto ja menetelmät}

Säilörehupaalit tehtiin Jokioisten kartanoiden Lintupajun tilalla. Rehun raaka-aineena oli toisen vuoden timotei-nurminata-nurmi, joka oli osittain tähkällä. Rehun kuiva-ainepitoisuus oli korjuuhetkellä $26,7 \%$ tai $39,1 \%$.

Rehu niitettiin niittomurskaimella (JF 3200 Top flex, murskaintyyppi iskukela) noin $8 \mathrm{~cm}: \mathrm{n}$ sänkeen ja paalattiin pyöröpaalaimella (Claas Rollant 250 RotoCut). Ajonopeus niittomurskaimella oli $10-12 \mathrm{~km} / \mathrm{h}$ ja paalaimella $5-7 \mathrm{~km} / \mathrm{h}$. Paalit sidottiin noin neljän kierroksen verkkosidonnalla ja kiedottiin (hinattava Kverneland 7517 -kiedontalaite) $750 \mathrm{~mm}$ leveään Trioplastmuoviin. Muovin limitys oli 50 prosenttia ja esikiristys 70 prosenttia. Kiedontamuovikerroksia paaleissa oli kuusi.

Paalit säilöttiin käyttäen säilöntäaineena AIV2000-happosäilöntäainetta, joka sisältää $55 \%$ muurahaishappoa, $24 \%$ ammoniumformiaattia, $5 \%$ propionihappoa, $1 \%$ bentsoehappoa ja $1 \%$ bentsoehapon estereitä. Biologisena säilöntäaineena käytettiin Bioprofit-säilöntäainetta, joka sisältää kahta bakteeria: Lactobacillus rhamnosus ja Propionibacterium freudenreichii ssp. shermanii. Osa paaleista tehtiin ilman säilöntäainetta painorehuksi. Silmämääräisesti tarkastellen paalit olivat hyvälaatuisia.

Mikrobialtistumista tutkittiin ottamalla ilmanäytteitä Jokioisten kartanoiden Lintupajun nuorkarjanavetassa ennen säilörehun jakamista karjalle (taustanäytteet, $n=12$ ) sekä säilörehun jakamisen aikana $(n=24)$. Taustanäytteet otettiin kiinteistä mittauspisteistä ja säilörehun jakamisen aikaiset näytteet kiinteistä mittauspisteistä sekä rehun jakajan hengitysvyöhykkeeltä. Näytteistä määritettiin elinkykyisten sienten (home- ja hiivasienet) pitoisuudet viljelymenetelmällä ja kokonaisitiöpitoisuudet epifluoresenssimikroskooppilaskennella (Palmgren ym. 1986). Elinkykyisten mikrobien pitoisuudet ilmoitetaan yksikössä $\mathrm{cfu} / \mathrm{m}^{3}(\mathrm{cfu}=$ colony forming unit $=$ pesäkkeen muodostava yksikkö) ja kokonaisitiöpitoisuudet yksikössä $\mathrm{kpl} / \mathrm{m}^{3}$. Mikrobipitoisuuksien välisten erojen merkitsevyyksiä verrattiin Wilcoxonin järjestyslukutestillä.

\section{Tulokset ja tulosten tarkastelu}

Pyöröpaalisäilörehun käsittelyn aikaiset ilman keskimääräiset mikrobipitoisuudet on esitetty kuvissa 1 ja 2. Happopaalien, joiden kuiva-ainepitoisuus oli 26,7\%, käsittelyn aikana ilman mikrobipitoisuudet 
olivat $10^{3}-10^{5} \mathrm{cfu} / \mathrm{m}^{3}$. Vastaavien ymppi- ja painorehupaalien käsittelyn aikaiset mikrobipitoisuudet vaihtelivat välillä $10^{3}-10^{4} \mathrm{cfu} / \mathrm{m}^{3}$. Kokonaisitiöpitoisuudet olivat $10^{6} \mathrm{kpl} / \mathrm{m}^{3}$. Mitatut pitoisuudet ovat samaa suuruusluokkaa, mitä on aikaisemmin havaittu navetoissa kuivaheinän ja kuivikkeiden jakamisen aikana (Hanhela ym. 1995, Lappalainen ym. 1996). Pitoisuudet olivat kuitenkin pienempiä kuin homeisen heinän käsittelyssä homepölykeuhkotiloilla mitatut pitoisuudet (Kotimaa ym. 1984). Tässä tutkimuksessa mukana olleet pyöröpaalit olivat mikrobiologisesti hyvälaatuisia (Rautiala ym. 2001), joten huonompilaatuisten paalien käsittelyn aikana mikrobipitoisuudet olisivat voineet olla huomattavasti suurempia.
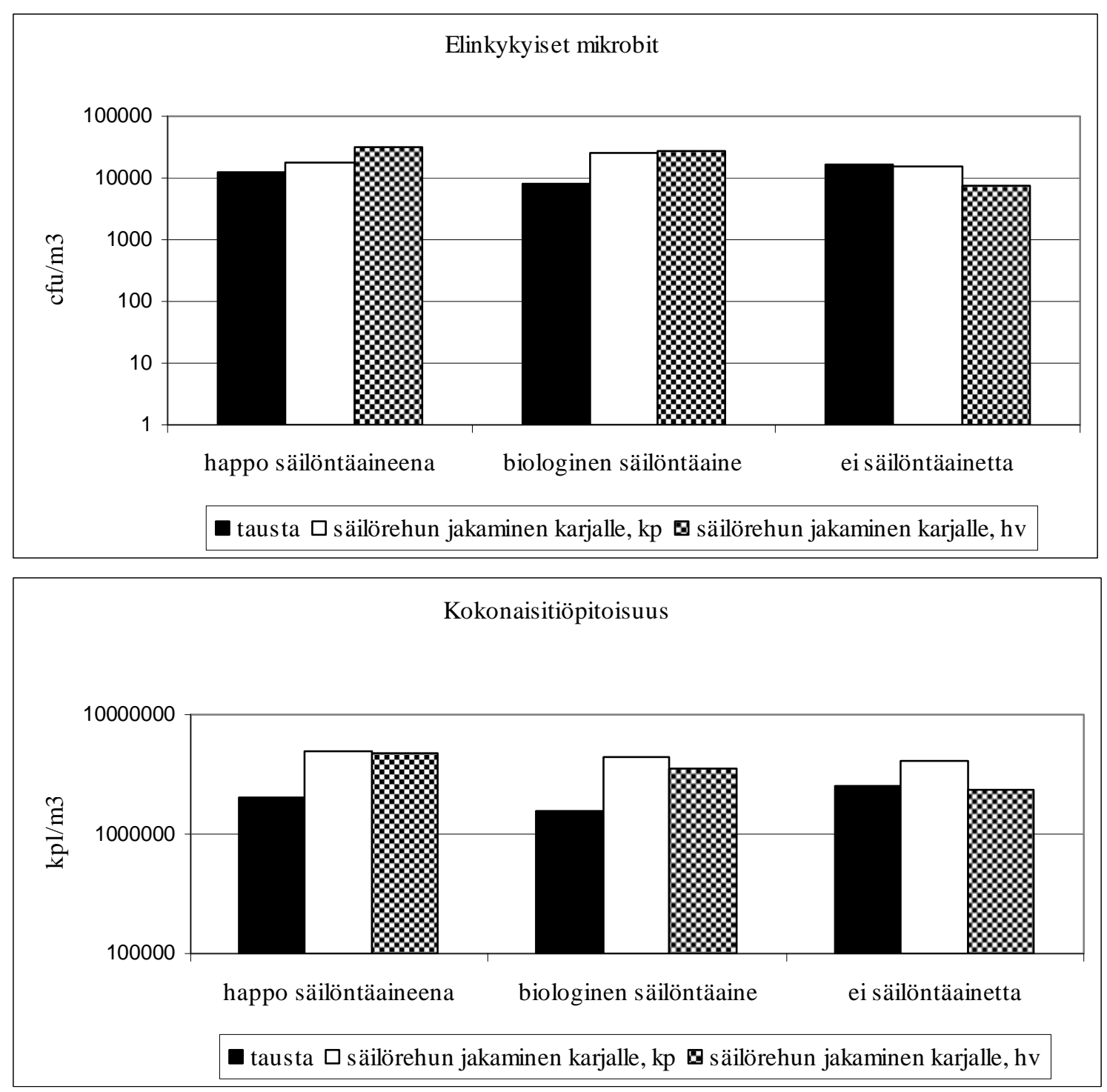

Kuva 1. Ilman mikrobipitoisuudet säilörehun kuiva-ainepitoisuudella 26,7\%. Pylväs kuvaa geometristä keskiarvoa. ( $\mathrm{kp}=$ kiinteäpistenäyte, hv = hengitysvyöhykenäyte)

Rehun jakajan hengitysvyöhykkeeltä otetuissa näytteissä ilman keskimääräiset mikrobipitoisuudet olivat suurimpia happopaaleja käsiteltäessä ja pienimpiä painorehupaaleja käsiteltäessä. Mikrobipitoisuuksien väliset erot eivät kuitenkaan olleet tilastollisesti merkitseviä.

Pyöröpaalien, joissa kuiva-ainepitoisuus oli 39,1\%, käsittelyn aikana ilman mikrobipitoisuudet olivat samaa suuruusluokkaa kuin kuiva-ainepitoisuudella 26,7\% (kuva 2). Rehun jakajan hengitysvyöhykkeeltä otetuissa näytteissä ilman keskimääräiset mikrobipitoisuudet olivat painorehupaalien käsittelyn aikana suurempia kuin happo- ja ymppipaalien käsittelyn aikana. Erot eivät olleet tilastollisesti merkitseviä. 

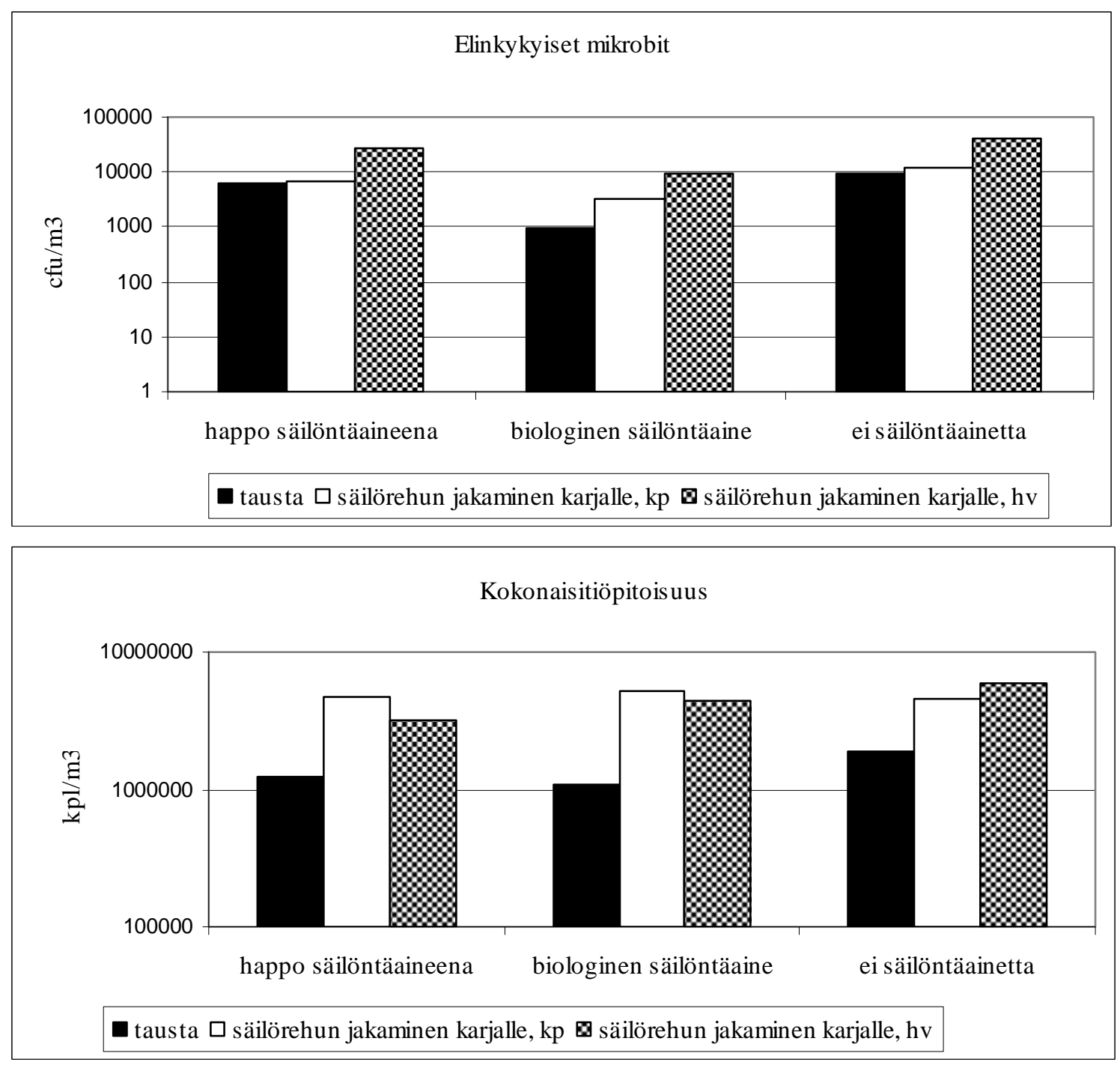

Kuva 2. Ilman mikrobipitoisuudet säilörehun kuiva-ainepitoisuudella 39,1\%. Pylväs kuvaa geometristä keskiarvoa. (kp = kiinteäpistenäyte, hv = hengitysvyöhykenäyte)

Pyöröpaalisäilörehun jakamisen aikana otetuissa ilmanäytteissä sienisuvusto oli hieman monipuolisempi kuin taustatilanteessa otetuissa näytteissä. Ennen säilörehun jakamista sekä rehun jakamisen aikana ilmassa esiintyi yleisimmin Penicillium- ja Wallemia-homesieniä sekä hiivoja. Nämä sienisuvut ovat olleet yleisimpiä myös aikaisemmin suomalaisissa navetoissa tehdyissä tutkimuksissa (Hanhela ym. 1995, Louhelainen ym. 1997).

\section{Johtopäätökset}

Maataloustyöntekijät voivat altistua varsin korkeille mikrobipitoisuuksille pyöröpaalisäilörehun käsittelyn yhteydessä. Jos rehun korjuu tai säilöäminen ei ole onnistunut, mikrobialtistumista voi tapahtua myös säilöntäaineilla säilöttyjä pyöröpaaleja käsiteltäessä. Pitoisuudet voivat olla samaa suuruusluokkaa, mitä on havaittu aikaisemmin maataloudessa kuivaheinän ja kuivikkeiden käsittelyn aikana. Tämän vuoksi on suositeltavaa käyttää P3-luokan suodattimella varustettua hengityksensuojainta pilaantunutta säilörehua käsiteltäessä. 


\section{Kirjallisuus}

Hanhela, R., Louhelainen, K. \& Pasanen, A-L. 1995. Prevalence of microfungi in Finnish cow barns and some aspects of the occurrence of Wallemia sebi and Fusaria. Scand. J. Work Environ. Health 21: 223-228.

Heida, H., Bartman, F. \& van deer Zee, S.C. 1995. Occupational exposure and indoor air quality monitoring in a composting facility. Am. Ind. Hyg. Assoc. J. 56:(1)39-43.

Karjalainen, A., Aalto, L., Jolanki, R., Keskinen, H., Paakkulainen, H. \& Savela, A. 1999. Ammattitaudit 1998. Työterveyslaitos, Helsinki.

Karjalainen, A., Aalto, L., Jolanki, R., Keskinen, H., Mäkinen, I. \& Savela, A. 2000. Ammattitaudit 1999. Työterveyslaitos, Helsinki.

Karjalainen, A., Aalto, L., Jolanki, R., Keskinen, H., Mäkinen, I. \& Saalo, A. 2001. Ammattiatudit 2000. Työterveyslaitos, Helsinki.

Karjalainen, A., Aalto, L., Jolanki, R., Keskinen, H., Mäkinen, I. \& Saalo, A. 2002. Ammattiatudit 2001. Työterveyslaitos, Helsinki.

Kotimaa, M.H., Husman, K.H., Terho, E.O. \& Mustonen, M. 1984. Airborne moulds and actinomycetes in the work environment of farmer's lung patients in Finland. Scand. J. Work Environ. Health 10: 115-119.

Lappalainen, S., Nikulin, M., Berg, S., Hintikka, E-L. \& Pasanen, A-L. 1996. Fusarium toxins and fungi associated with handling of grain on eight Finnish farms. Atmos. Environ. 30: 3059-3065.

Louhelainen, K., Kangas, J., Reiman, M. \& Kalliokoski, P. 1997. Farmer's exposure to dusts and gases in modern Finnish cubicle cow barns. Agric. Food Sci. Finland 6: 207-217.

Palmgren, U., Ström, G., Blomqvist, G. \& Malmberg, P. 1986. Collection of airborne micro-organisms on nuclepore filters: estimation and analysis-CAMNEA-method. J. Appl. Bacteriol. 61: 401-406.

Rautiala, S., Rissanen, P. \& Reiman, M. 2001. Pyöröpaalisäilörehun mikrobiologiset riskit maataloustyöntekijöille. Loppuraportti Maatalousyrittäjien eläkelaitokselle. Työterveyslaitos, Kuopio.

Riihimäki, H., Kurppa, K., Karjalainen, A., Aalto, L., Jolanki, R., Keskinen, H., Mäkinen, H., Mäkinen, I. \& Saalo, A. 2003. Ammattitaudit 2002. Työterveyslaitos, Helsinki.

Työterveys ja maatalous Suomessa 2004-tutkimus. Kuopion aluetyöteveyslaitoksen meneillään oleva tutkimus. 